\title{
SISTEM PENDUKUNG KEPUTUSAN BERBASIS AHP UNTUK MEMBANTU PENENTUAN PENGISIAN JABATAN DI BANDAR LAMPUNG STUDY KASUS: PT PRUDENTIAL LIFE ASSURANCE
}

\author{
Dewi Sari Indah*1 \\ Taqwan Thamrin ${ }^{\# 2}$ \\ ${ }^{*}$ I\#2 Program Studi Sistem Informasi \\ Fakultas Ilmu Komputer, \\ Universitas Bandar Lampung \\ Jl. Zainal Abidin Pagar Alam No. 26 \\ Labuhan Ratu Bandar Lampung 35142
}

\begin{abstract}
PT Prudential Life Assurance di Bandar Lampung sebagai perusahaan yang bergerak di bidang jasa, terutama asuransi jiwa.Pada PT Prudential Life Assurance di Bandar Lampung Bandar Lampung, Pegawai adalah bagian yang sangat penting bagi perusahaan untuk mencapai tujuannya. Sebelumnya Pengisian Jabatan dilakukan secara Manual, dengan mempertimbangkan kerja dan hasil wawancara yang dilakukan oleh Manajer Cabang, hal ini seringkali menimbulkan penilaian yang kurang obyektif .Tujuan dari pembuatan sistem ini dalam rangka menciptakan sistem yang ditujukan untuk menilai Pegawai yang memenuhi syarat untuk mengisi posisi dengan menggunakan Metode AHP.Sistem pendukung keputusan berdasarkan metode AHP telah memberikan hasil bahwa Pegawai yang mungkin memenuhi persyaratan untuk mengisi posisi yang kosong sesuai dengan kriteria yang telah ditentukan. Berdasarkan perhitungan bahwa untuk hasil yang diperoleh memiliki tingkat error menggunakan perhitungan AHP 0,001115 atau memiliki akurasi 99,89\%. Dengan demikian, dapat disimpulkan bahwa perhitungan dengan menggunakan metode AHP lebih akurat.
\end{abstract}

Keyword : Sistem Pendukung Keputusan , AHP , Java, UML

\section{PENDAHULUAN}

PT Prudential Life Assurance Bandar Lampung merupakan perusahaan asuransi jiwa yang dimana perusahaan ini milik swasta. Kegiatan utama perusahaan PT Prudential Life Assurance Bandar Lampung yaitu membantu masyarakat dalam merencanakan keuangan di masa yang akan datang. Bidang asuransi pada PT Prudential Life Assurance Bandar Lampung yaitu asuransi jiwa. Pada PT Prudential Life Assurance Bandar Lampung, pegawai merupakan bagian yang sangat penting bagi perusahaan dalam mencapai tujuan perusahaan, maka dari itu perusahaan dalam proses penerimaan pegawai mempunyai kriteria-kriteria khusus agar nantinya sesuai dengan kebutuhan perusahaan. AHP (Analytical Hierarkhi Process) pada dasarnya proses pengambilan keputusan adalah memilih suatu alternatif. Berdasarkan dari latar belakang yang telah dibahas sebelumnya, maka penulis akan mengambil judul skripsi "Sistem Pendukung Keputusan Berbasis AHP untuk Membantu Penentuan Pengisian Jabatan di PT Prudential Life Assurance Bandar Lampung".

a. Identifikasi Masalah

Berdasarkan uraian latar belakang masalah yang telah diuraikan, maka permasalahan yang timbul dalam penelitian ini antara lain:
1. Penentuan Pengisian jabatan yang dilakukan PT Prudential Life Assurance di Bandar Lampung masih melakukanpenilaian secara manual dengan mempertimbangkan faktor masa kerja dan hasil interview yang dilakukan oleh Branch Manager.

2. Belum adanya aplikasi sistem pendukung keputusan untuk membantu pengisian jabatan pada PT Prudential Life Assurance di Bandar Lampung yang lebih terperinci dan Akurat.

b. Batasan Masalah

Penulisan Tugas Akhir ini diharapkan lebih fokus dan lebih terarah, maka perlu diadakan batasan-batasan sebagai berikut :

1. Pada pemilihan pegawai yang akan mengisi jabatan yang kosong menggunakan5 aspek penilaian yaitu : Kompetensi, Perilaku, Kepemimpinan, Prestasi Kerja dan Disiplin.

2. Penelitian hanya dilakukan kepada Pegawai Internal Perusahaan.

c. Rumusan Masalah

Berdasarkan latar belakang yang telah diuraikan diatas, maka penulis merumuskan masalah yaitu :

Apakah aplikasi sistem pendukung keputusan sebagai alat bantu pengisian jabatan berbasis AHP di PT Prudential Life Assurance Bandar Lampung 


\section{d. Tujuan dan Manfaat Penelitian}

\section{Tujuan Penelitian}

Berdasarkan pada permasalahan yang telah diuraikan sebelumnya, maka tujuan yang ingin dicapai dalam penelitian ini adalah sebagai berikut :

a) Membandingkan proses perhitungan dengan menggunakan metode AHP dengan perhitungan yang dilakukan secara manual dalam proses pengisian jabatan, sehingga dapat menghasilkan penilaian yang optimal dan akurat dalam memberikan penilaian.

b) Membangun sebuah aplikasi pendukung keputusan pada PT Prudential Life Assurance Bandar Lampung. Menerapkan metode AHP kedalam sebuah aplikasi pendukung keputusan.

2. Manfaat Penelitian

berikut :

Adapun manfaat penelitian ini adalah sebagai

a) Berdasarkan hasil dari penelitian akan membantu pengambil keputusan dalam memilih pegawai yang sesuai untuk mengisi jabatan yang kosong sesuai dengan kriteria jabatan.

b) Dengan adanya aplikasi ini nantinya diharapkan dapat memberikan informasi yang cepat, tepat dan akurat sesuai kebutuhan dalam membantu proses pengisian jabatan pegawai PT Prudential Life Assurance Bandar Lampung.

\section{e. Kerangka Pemikiran}

Proses yang dilakukan dalamSistem Pendukung Keputusan Berbasis AHP untukMembantu Penentuan Pengisian Jabatan PT Prudential Life Assurance Di Bandar Lampung, dapat dijabarkan melalui kerangka pemikiran.

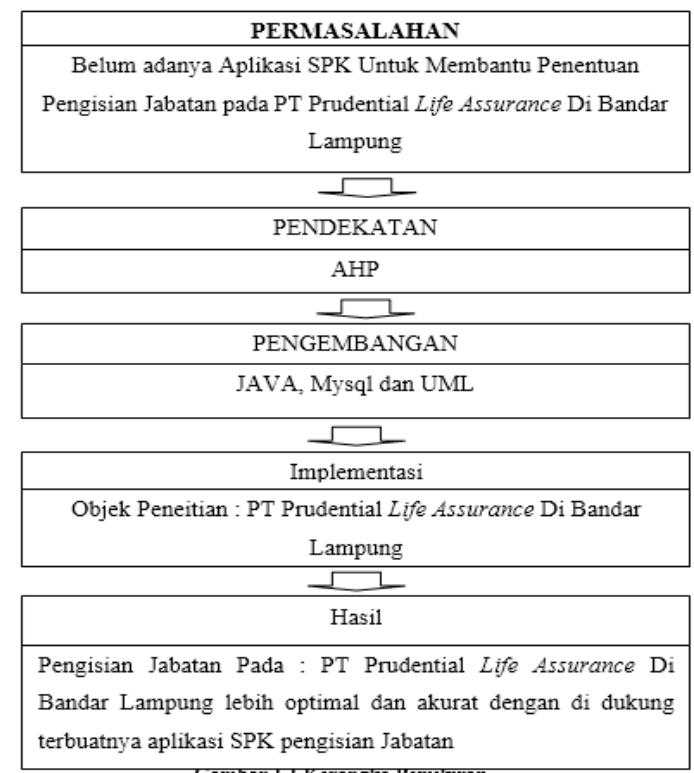

Gambar 1.1 Kerangka Pemikiran

\section{TINJAUAN PUSTAKA DAN LANDASAN TEORI}

\section{a. Tinjauan Pustaka}

Penelitian terdahulu yang telah dilakukan atau yang berkaitan dengan penelitian ini antara lain :

1. Penelitian Adriyendi Rahmadi (2011 : 11). Dengan Judul “ Aplikasi AHP Sebagai Model SPK Pemilihan Dosen "Tujuan Penelitian ini dilakukan untuk menerapkan Analytical Hierarchy Process (AHP) digunakan sebagai model Sistem Pendukung Pengambilan Keputusan dalam pemilihan staf instruktur di Batusangkar STAIN.

2. Penelitian Supriyono, dkk (2007 : 22). Dengan Judul "Sistem Pemilihan Pejabat Struktural Dengan Metode AHP“. Tujuan Penelitiannya adalah membuat suatu simulasi sebagai alat untuk memilih pejabat struktural.

\section{b. Landasan Teori}

1. Sistem Pendukung Keputusan / Decision Support System (DSS)

DSS merupakan sistem informasi interaktif yang menyediakan informasi, pemodelan, dan pemanipulasian data. Sistem itu digunakan untuk membantu pengambilan keputusan dalam situasi yang semiterstruktur dan situasi yang tidak terstruktur di mana tak seorang pun tahu secara pasti bagaimana keputusan seharusnya dibuat Alter (2010 : 22).

DSS lebih ditunjukan untuk mendukung manajemen dalam melakukan pekerjaan yang bersifat analitis dalam situasi yang kurang terstruktur dan dengan kriteria yang kurang jelas.

a) Membantu manajer dalam pengambilan keputusan atas masalah semi terstruktur.

b) Memberikan dukungan atas pertimbangan manajer dan bukan untuk menggantikan fungsi manajer.

c) Meningkatkan efektivitas keputusan yang diambil manajer lebih daripada perbaikan efisiensinya.

d) Kecepatan komputasi. Komputer memungkinkan para pengambil keputusan untuk melakukan banyak komputasi secara cepat dengan biaya yang rendah.

e) Peningkatan produktivitas. Membangun satu kelompok pengambil keputusan, terutama para pakar, bisa sangat mahal. Pendukung terkomputerisasi bisa mengurangi ukuran kelompok dan memungkinkan para anggotanya untuk berada di berbagai lokasi yang berbeda-beda (menghemat biaya perjalanan). 
f) Dukungan kualitas. Komputer bisa meningkatkan kualitas keputusan yang dibuat. Sebagai contoh, semakin banyak data yang diakses, makin banyak juga alternative yang bisa dievaluasi.

g) Berdaya saing. Manajemen dan pemberdayaan sumber daya perusahaan. Tekanan persaingan menyebabkan tugas pengambil keputusan menjadi sulit.

h) Mengatasi keterbatasan kognitif dalam pemrosesan dan penyimpanan. Menurut Simon, otak manusia memiliki kemampuan yang terbatas untuk memproses dan menyimpan informasi.

\section{Analytical Hierarkhi Process (AHP)}

AHP (Analytical Hierarkhi Process) pada dasarnya proses pengambilan keputusan adalah memilih suatu alternatif. Peralatan utama AHP adalah sebuah hierarki fungsional dengan input utamanya persepsi manusia.

\section{a) Prinsip dasar AHP}

Dalam menyelesaikan permasalahan denan AHP ada beberapa prinsip yang harus dipahami, diantaranya adalah :

\section{Membuat hierarki}

Sistem yang kompleks bisa dipahami dengan memecahnya menjadi elemen-elemen pendukung, menyusun elemen secara hierarki, dan menggabungkan atau mensistensinya.

Menurut Suryadi dan Rahmadhani (2002 : 16) pada dasarnya langkah-langkah dalam metode AHP adalah sebagai berikut :

a. Mendefenisikan masalah dan menentukan solusi yang diinginkan.

b. Membuat struktur hirarki yang diawali dengan tujuan umun, dilanjutkan dengan kriteria-kriteria dan alternatif - alternatif pilihan yang diinginan di rangking.

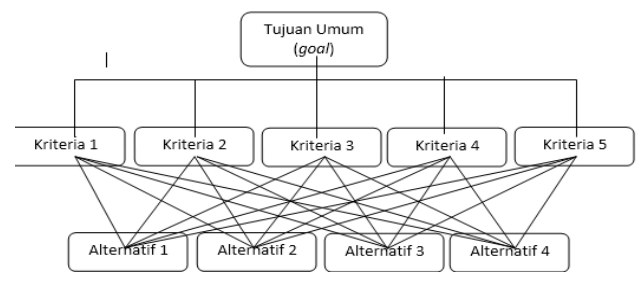

Gambar 2.1 Struktur Hirarki dalam AHP

c. Membuat Matriks perbandingan berpasangan yang menggambarkan zontribusi relatif atau pengaruh setiap elemen terhadap masingmasing tujuan dan kriteria yang setinggkat datanya.

2. Penilaian kriteria dan alternatif

Kriteria dan alternatif dilakukan dengan perbandingan berpasangan. Menurut Saaty (1998 : 10) untuk berbagai persoalan, skala 1 sampai 9 adalah skala terbaik untuk mengekspresikan pendapat.

3. Syntheis of priority (menetukan prioritas) Untuk setiap kriteria dan alternatif, perlu dilakukan perbandingan berpasangan.

\section{Logical Consistency (Konsistensi Logis)}

Konsistensi memilki dua makna. Petama, objek-objek yang serupa bisa dikelompokkan sesuai dengan keseragaman dan relevansi.

\section{Prosedur AHP}

Pada dasarnya, prosedur atau langkahlangkah dalam metode AHP meliputi :

a. Mendefinisikan masalah dan menentukan solusi yang diinginkan lalu menyusun hierarki dari permasalahan yang ada.

b. Menentukan prioritas elemen.

c. Sintesis.

Pertimbangan-pertimbangan terhadap perbandingan berpasangan disentesis untuk memperoleh keseluruhan prioritas.

d. Mengukur Konsistensi.

Dalam pembuatan keputusan, penting untuk mengetahui seberapa baik konsistensi yang ada karena kita tidak menginginkan keputusan berdasarkan pertimbangan dengan konsistensi rendah.

e. Hitung konsistensi Index :

(CI) dengan rumus : $(\mathrm{CI})=\left(\lambda_{\text {maks-n }}\right) / \mathrm{n}$

Dimana

$\mathrm{n}$ = banyaknya elemen

f. Hitung Rasio Konsistensi/Consistency Ratio (CR) dengan rumus :

$$
\mathrm{CR}=\mathrm{CI} / \mathrm{RC}
$$

Dimana

$\mathrm{CR}=$ Consistency Ratio

$\mathrm{CI}=$ Consistency Index

IR = Indeks Random Consistency

g. Memeriksa consistency hierarki.

Daftar Indeks Random Konsistensi (IR) bisa dilihat pada Tabel 2.2 berikut :

Tabel 2.1Daftar Indeks Random Konsistensi

\begin{tabular}{|l|l|}
\hline UkuranMatriks & Nilai IR \\
\hline 1,2 & 0,00 \\
\hline 3 & 0,58 \\
\hline 4 & 0,90 \\
\hline 5 & 1,12 \\
\hline 6 & 1,24 \\
\hline 7 & 1,32 \\
\hline 8 & 1,41 \\
\hline 9 & 1,45 \\
\hline 10 & 1,49 \\
\hline
\end{tabular}




\begin{tabular}{|l|l|}
\hline 11 & 1,51 \\
\hline 12 & 1,48 \\
\hline 13 & 1,56 \\
\hline 14 & 1,57 \\
\hline 15 & 1,59 \\
\hline
\end{tabular}

Pengisian jabatan adalah kegiatan untuk memperoleh pegawai yang efektif yang akan mengisi jabatan-jabatan kosong perusahaan.

\section{Ruang Lingkup Pengisian Jabatan}

Ruang lingkup pengisian jabatan padaPada PT Prudential Life Assurance di Bandar Lampung adalah :

\section{a) Pengadaan (Procurement)}

Proses penarikan, seleksi, penempatan, orientasi, dan induksi untuk mendapatkan pegawai baik kualitas maupun kuantitasnya sesuai dengan kebutuhan perusahaan.

\section{b) Penarikan (Recruiting)}

Kegiatan mencari dan mempengaruhi tenaga kerja agar mau melamar lowongan pekerjaan yang masih kosong di perusahaan.

Faktor-faktor yang mempengaruhi :

1) Balas jasa

2) Status Pegawai

3) Kesempatan promosi

4) Job specification

5) Metode penarikan

6) Penawaran tenaga kerja

Sumber-sumber penarikan :

1) Sumber Internal

Ditarik dari pegawai yang telah ada dalam perusahaan. Penarikan dilakukan dengan cara "mutasi atau transfer",baik sifatnya vertikal (promosi-demosi) maupun horizontal.

2) Sumber Eksternal

Mengisi lowongan jabatan yang kosong ditarik dari orang-orang diluar perusahaan.

\section{c) Seleksi (Selection)}

Serangkaian kegiatan yang dilaksanakan untuk memutuskan apakah seorang pelamar diterima/ditolak, tetap/tidaknya seorang pekerja ditempatkan pada posisi-posisi tertentu yang ada dalam organisasi.

\section{d) Penempatan (Placement)}

Kegiatan untuk menempatkan orang-orang yang telah lulus seleksi pada jabatan-jabatan tertentu sesuai dengan uraian pekerjaan dan klarifikasi-klarifikasi pekerjanya.

\section{e) Pemberhentian (Separation)}

Putusnya hubungan kerja seseorang karyawan dengan suatu perusahaan.Pemberhentian (PHK) ini disebabkan oleh keinginan perusahaan, keinginan karyawan, kontrak kerja habis, peraturan perburuhan, pensiun dan atau meninggal dunia.

\section{Pengertian Java}

JAVA adalah sebuah bahasa pemrograman yang diciptakan oleh Sun Microsystems, sebuah perusahaan besar di Amerika Serikat.

\section{Java IDE Netbeans 6.5}

IDE NetBeans merupakan Intergrated Development Environment (IDE) yang telah banyak dipakai untuk mengembangkan program dalam bahasa Java.

6. Pengertian $M y S Q L$

MySQL merupakan software RDBMS (atau server database) yang dapat mengelola database dengan sangat cepat, dapat menampung data dalam jumlah sangat besar, dapat diakses oleh banyak user (multi-user), dan dapat melakukan suatu proses secara sinkron atau berbarengan (multitreaded).

kelebihan dari $M y S Q L$ :

a) Fleksibel

MySQL dapat digunakan untuk mengmbangkan aplikasi desktop maupun aplikasi web dengan menggunakan teknologi yang bervariasi. Ini berarti bahwa MySQL memiliki fleksibelitas terhadap teknologi yang akan digunakan sebagai pengembang aplikasi.

b) Performa Tinggi

MySQL memilki mesin query dengan performa tinggi, dengan demikian proses transaksional dapat dilakukan dengan sangat cepat.

c) Lintas Platform

MySQL dapat digunakan pada platform atau lingkungan (dalam hal ini Sistem Operasi) yang beragam, bisa Microsoft Windows, Linux, atau UNIX.

d) Gratis

MySQL dapat digunakan secara gratis.Meskipun demikian, ada juga software $M y S Q L$ yang bersifat komersial.Biasanya yang sudah ditambahi dengan kemampuan spesifik dan mendapat pelayanan dari techinal support.

e) Proteksi Data yang Handal

Perlindungan terhadap keamanan data merupakan hal nomor satu yang dilakukan oleh para professional di bidang database

f) Komunitas Luas

Karena penggunanya banyak maka $M y S Q L$ memilki komunitas yang luas. Hal ini berguna jika kita menemui sautu permasalahan dalam proses pengolahan data menggunakan MySQL.

7. Diagram Alir Dokumen (Mapping chart )

Menurut Andi Kristanto Diagram Alir Dokumen merupakan diagram alir yang memodelkan masukan, keluaran, proses maupun transaksi dengan menggunakan simbol - simbol 
tertentu, diagram alir dokumen digunakan menggambarkan sistem secara fisik.

\section{Pengertian $\boldsymbol{U} M L$}

Menurut Widodo, Prabowo Pudjo, dan Herlawati (2011) Unified Modeling Language $(U M L)$ yang berarti bahasa pemodelan standar. Jika menggunakan $U M L$ harus dapat membuat model-model yang dapat berhubungan satu dengan yang lainnya dengan mengikuti standar yang ada.

\section{a) Object Oriented}

Orientasi objek merupakan teknik dalam menyelesaikan masalah yang kerap muncul dalam pengembangan perangkat lunak. Teknik ini merupakan titik kulminasi dalam menemukan cara yang efektif dalam membangun system dan menjadi metode yang paling banyak dipakai oleh para pengembang perangkat lunak saat ini.

\section{b) Use Case Diagram}

Menurut Widodo, Prabowo Pudjo, dan Herlawati (2011 : 10) use case diagram adalah diagram yang memperlihatkan himpunan use case dan aktor-aktor (suatu jenis khusus dari kelas).

c) Sequence Diagram

Menurut Widodo, Prabowo Pudjo, dan Herlawati (2011 : 11) sequence diagram adalah diagram yang menggambarkan interaksi yang menekankan pada pengiriman pesan dalam suatu waktu tertentu.

d) Activity Diagram

Menurut Widodo, Prabowo Pudjo, dan Herlawati (2011 : 11) activity diagram adalah diagram tipe khusus dari diagram status yang memperlihatkan aliran dari suatu aktivitas ke aktivitas yang lainnya dalam suatu sistem.

e) Class Diagram Menurut Widodo, Prabowo Pudjo, dan Herlawati (2011 : 39) class adalah satu set objek yang memilki atribut dan perilaku yang sama.

3. METODE PENELITIAN

a. Analisa Kebutuhan

1. Perangkat Keras

Perangkatkeras yang

digunakandalampenelitianadalahsebagaiberikut:

a) Processor Dual Core 2,7 Ghz

b) Memory RAM 2 GB

c) Harddisk $80 \mathrm{~GB}$

d) Monitor 17 inchi, dengan resolusi 1024 x 768

e) Keyboard dan Mouse

Semakin tinggi spesifikasi hardware yang digunakan maka semakin baik.

\section{Perangkat Lunak}

Perangkatlunak

yang

digunakandalampenelitianadalahsebagaiberikut: a) Sistem Operasi Microsoft Windows 7 Profesional.

b) Java sebagai bahasa pemograman.

c) MySQL sebagai database.

Pengguna dan pengembang bersama-sama mendefinisikan format seluruh perangkat lunak, mengidentifikasikan semua kebutuhan, dan garis besar sistem yang akan dibuat.

\section{b. Metode Pengembangan Sistem}

Metode yang digunakan dalam pengembangan perangkat lunak menerapkan metode waterfall.Dimodelkan setelah siklus rekayasa konvensional, model sekuensial ini meliputi beberapa kegiatan berikut :

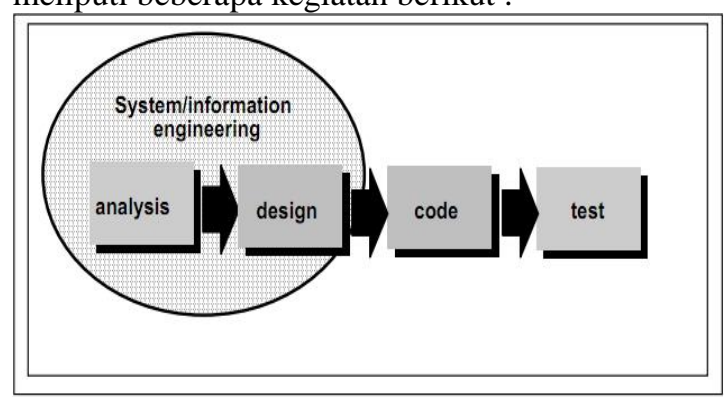

Gambar 3.1Metode Waterfall

\section{System/information engineering and modeling}

Penulis melakukan survei atau pengamatan langsung terhadap proses pengisian jabatan. Tahapan survei yang dilakukan adalah sebagai berikut :

a) Mewawancarai langsung ke bagian HRD perusahaan tentang proses pengisian jabatan.

b) Mencatat apa saja yang menjadi penilaian pada perusahaan terhadap proses pengisian jabatan.

2. Software requirements analysis

a) Tahapan ini dilakukan untuk menganalisis kebutuhan sistem dari kebutuhan software dan hardware serta kebutuhan informasi yang dibutuhkan oleh peneliti. Pengamatan (Observation)

b) Pengumpulan data denganmengamatiatauobservationyaitumetod epengumpulan data dengancarapengamatan danpencatatansecaralangsung.

3. Software requirements analysis

Tahapan ini dilakukan untuk menganalisis kebutuhan sistem dari kebutuhan software dan hardware serta kebutuhan informasi yang dibutuhkan oleh peneliti.

a) Pengamatan (Observation)

Pengumpulan

data denganmengamatiatauobservationyaitumetodepen gumpulan data dengancarapengamatan danpencatatansecaralangsung.Penelitimelakukanpe ngamatanpada PT Prudential Life Assurance Di Bandar Lampung 
b) Studi Literatur

Merupakanmetodepengumpulan dengancaramembaca, mencatat, danmengumpulkan secarateoritisdaribuku-buku berhubungandenganpengisianjabatan, analisisdandesainsistem, $U M L$.

\section{Design}

Tahap penerjemahan dari keperluan atau data yang telah dianalisis ke dalam bentuk yang mudah dimengerti.

\section{Code generation}

Desain harus diterjemahkan ke dalam bentuk mesin yang dapat dibaca.Langkah pembuatan kode melakukan tugas ini.

\section{Testing}

Setelah kode telah dihasilkan, pengujian program dimulai.

\section{Sistem Yang Diusulkan}

Pada sistem yang diusulkan ini menggambarkan tiga entity, yaitu entity Admin, SPK dengan AHP dan Pimpinan.Seorang admin dapat masuk dengan mengisikan username dan password yang benar untuk dapatmasuk ke dalam sistem.

\section{Rancangan Sistem}

a) Use Case Diagram

Use case diagram merupakan salah satu diagram dalam bahasa pemodelan $U M L$ yang dapat menggambarkan kegiatan yang dilakukan oleh aktor secara garis besar, dan hubungan antara aktor dengan tiap kegiatan (actor - use case) atau hubungan antara kegiatan (use case-use case).

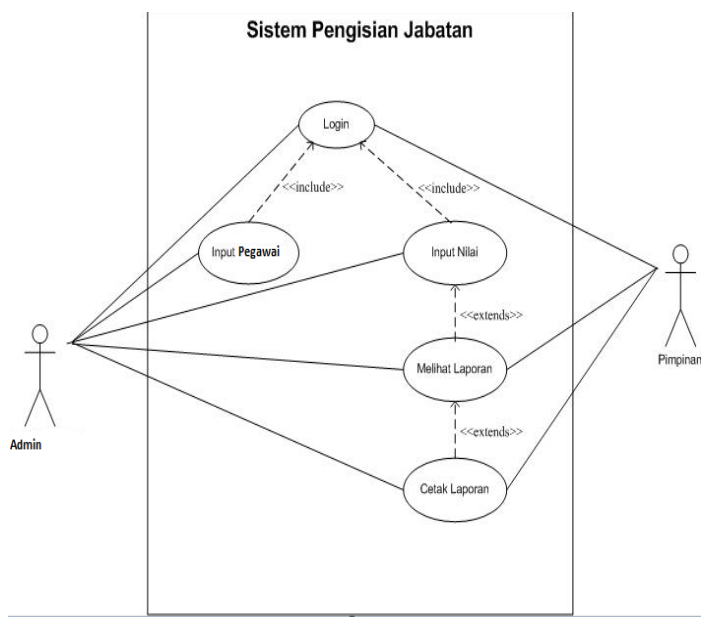

Gambar 3.2Use Case Diagram

\section{b) Sequence Diagram}

Sequence diagram merupakan alur dari sebuah pesan-pesan yang akan dikirimkan ke aktor yang mendeskripsikan tentang alur berjalannya sistem.

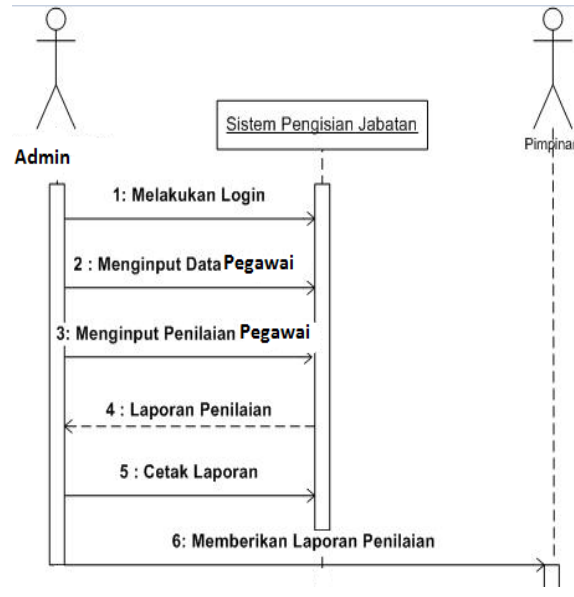

Gambar 3.3Sequence Diagram

\section{c) Activity Diagram}

Activity diagram menggambarkan berbagai alir aktivitas dalam sistem yang sedang dirancang,bagaimana masing-masing alir berawal, decision yang mungkin terjadi, dan bagaimana mereka berakhir.

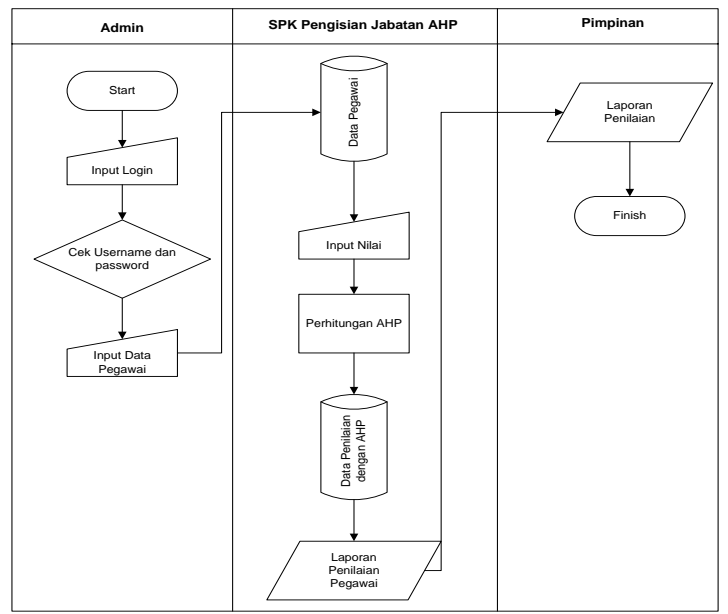

Gambar 3.4Activity Diagram

\section{d) Rancangan Basis Data}

Sistemyang dibuat akan menggunakan basis data sebagai tempat penyimpanan seluruh data yang dimasukkan. Rancangan basis data terdiri dari beberapa tabel yang saling berkaitan antara tabel yang satu dengan tabel yang lainnya.

\section{e) Rancangan Form Login}

Form login adalah form yang digunakan oleh petugas untuk dapat masuk ke dalam aplikasi. Pada formlogin terdapat dua komponen input berupa User dan password. 


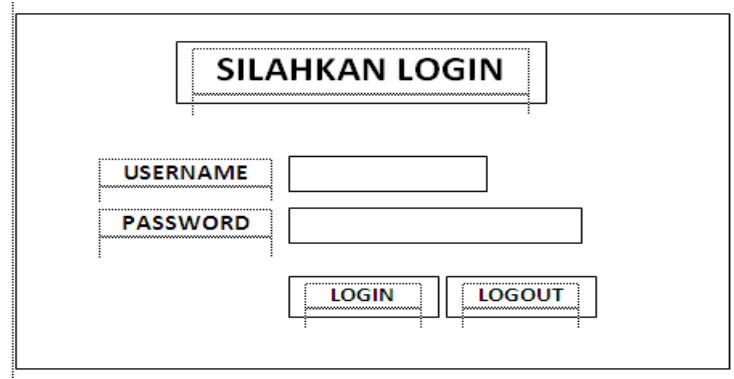

Gambar 3.5Rancangan Form Login

\section{f) Rancangan Form Menu Utama}

Form menu utama adalah form awal yang akan tampil pada saat Admin berhasil login.

g) Rancangan Form Data Master Pegawai

Form Data Master Pegawai merupakan form yang berisi data pegawai yang akanmengikuti proses seleksi pengisian jabatan.

\section{h) Rancangan Form Data Kriteria}

Form Data Kriteria merupakan form yang berisi data kriteria yang akan digunakan dalam proses pengisian jabatan. Berikut rancangan form data kriteria :

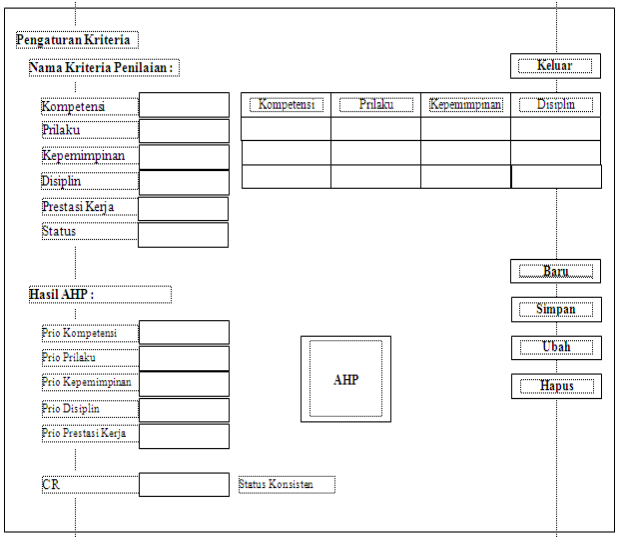

Gambar 3.6Rancangan Form Kriteria

i) Rancangan Form Penilaian

Form ini berisi penilaian seluruh pegawai yang akan mengikuti proses pengisian jabatan, penilaian meliputi penilaian dengan metode AHP serta penilaian manual.

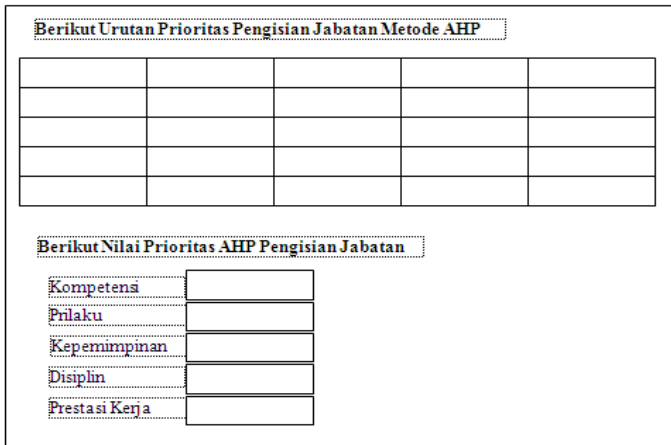

Gambar 3.7Rancangan Form Penilaian

\section{j) Form View Laporan}

Form ini akan berfungsi untuk melihat seluruh hasil dari proses pengisian jabatan berdasarkan posisi pengisian jabatan dan tanggal proses pengisian jabatan yang telah di proses.

\section{HASIL DAN PEMBAHASAN}

\section{a. Sejarah PT Prudential Life Assurance Di Bandar Lampung}

sejarah berdirinya pt prudential life assurance di bandar lampung didirikan pada tahun 2006, pt prudential life assurance di bandar lampung merupakan bagian dari mitra di prudential indonesia, salah satu mitra sebuah grup perusahaan jasa keuangan terkemuka dari indonesia dan inggris yang mengelola dana yang mengembangkan asuransi di indonesia dengan menggabungkan pengalaman beberapa mitra di pt prudential life assurance di bandar lampung di bidang asuransi jiwa dengan pengetahuan tata cara bisnis lokal, pt prudential life assurance di bandar lampung memiliki komitmen untuk mengembangkan bisnisnya di indonesia khususnya di bandar lampung.struktur jabatan di pt prudential life assurance di bandar lampung.

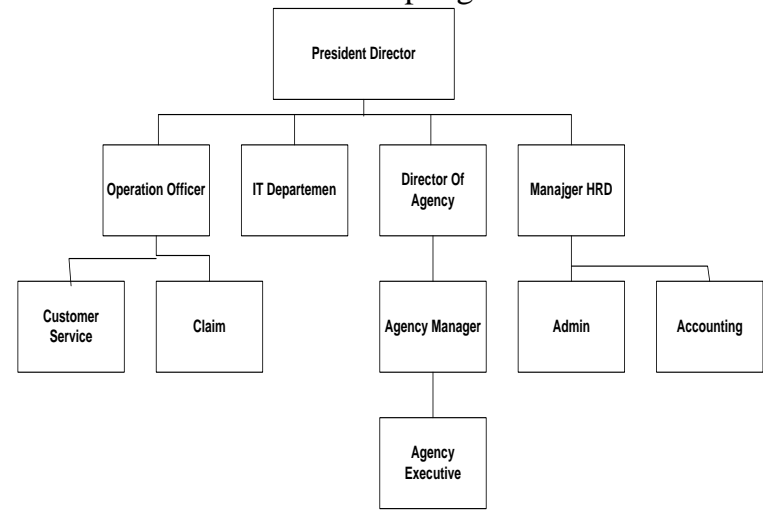

Gambar 4.1Struktur Organisasi PT Prudentiallife assurance bandar lampung

\section{b. Aplikasi Program}

Perancangan aplikasi Pengisian Jabatan dengan metode AHP ini terdiri dari beberapa tampilan, sehingga program akan dengan mudah melakukan proses pengolahan data.

\section{c. Form Login}

Form Login ini terdapat ada dua texboxt masukan yaitu User ID dan Password. User terlebih dahulu memasukkan User ID dan Password terlebih dahulu jika ingin mengakses 


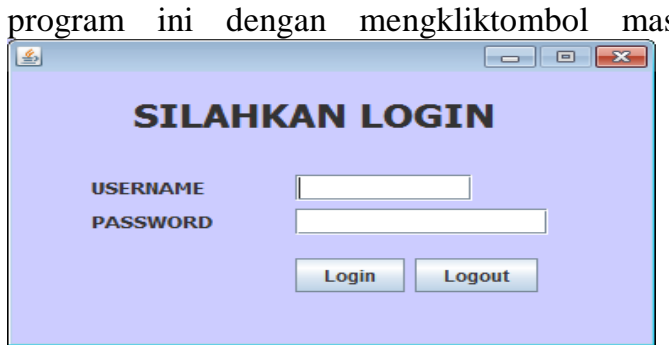

Gambar 4.2 form login

\section{d. Form Menu Master Pegawai}

Pada form ini merupakan form master pegawai yang didalamnya terdapat inputan seperti no id pegawai, nama jabatan, jabatan dan pilih jabatan. Dalam form ini sistem dapat memanipulasi data seperti pada tombol simpan data, tombol ubah data, tombol hapus data serta tombol baru dan tombol keluar.

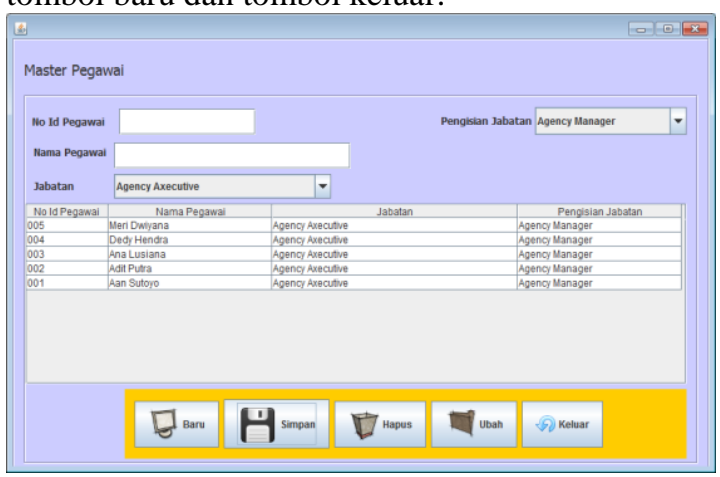

\section{e. Form Menu Kriteria}

Padaform Menu Kriteria ini berfungsi untuk mengatur kriteria-kriteria berdasarkan nama kriteria penilaian yang sudah ditentukan dalam menggunakan metode AHP.

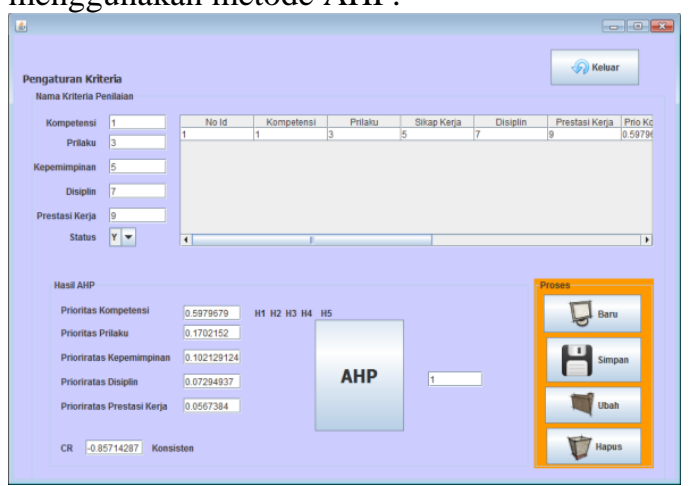

Gambar 4.4 Form Menu Kriteria

\section{f. Form Menu Penilaian Jabatan}

Pada form penilaian jabatan ini merupakan form penilaian yang akan diproses dengan metode AHP, tampilan form menu penilaian jabatan ini dapat dilihat pada gambar 4.6 sebagai berikut.

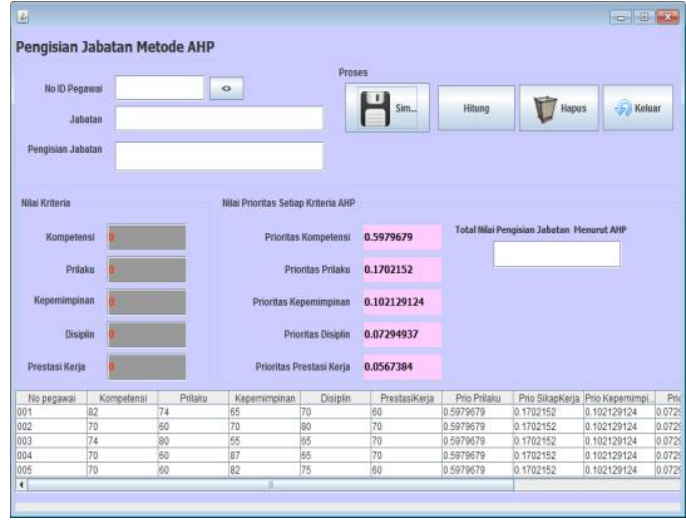

Gambar 4.5 Form Menu Penilaian Jabatan g. Form View Laporan

Menu Laporan ini berfungsi untuk melihat hasil proses perhitungan yang telah dilakukan pada beberapa pegawai yang dilakukan seleksi pengsian jabatan. Tampilan form view laporan pengisian jabatan ini dapat dilihat pada gambar 4.7 sebagai berikut.

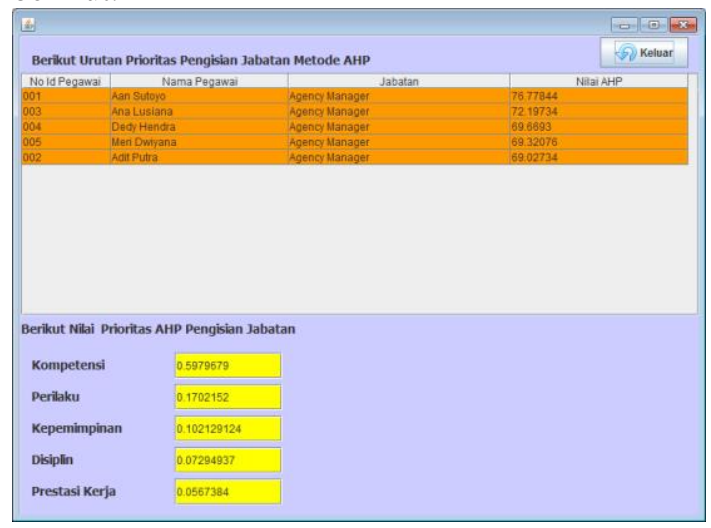

Gambar 4.6 Form View Laporan Pengisian Jabatan

\section{h. Pengujian Perangkat Lunak}

Pada pengujian sistem ini, penulis menggunakan dua metode, yaitu metode White Box dan Black Box.

\section{i. Sistem Pengujian White Box}

Metode white box ini merupakan metode desain test case yang menggunakan struktur kontrol desain prosedural dalam memperoleh test case.

\section{KESIMPULAN DAN SARAN}

\section{a. Kesimpulan}

Sistempengisian Jabatanpada PT Prudential Life Assurance Bandar Lampung bisa dijadikan dasar pengambilan keputusan, secara Objektif yang dapat dipertanggungjawabkan dengan dukungan perhitungan yang dilakukan dengan Analytic Hierarchiy Process (AHP) sebagai model sistem pendukung keputusan dengan Perbandingan tingkat Akurasi penggunaan Metode Analytic Hierarchiy Process (AHP) sebagai model 
sistem pendukung keputusan untuk pengisian jabatan dengan nilai akurasi yaitu 99,9662\% Di bandingkan perhitungan secara manual. Aplikasi Sistem Pendukung Keputusan Pengisian Jabatan menggunakan Metode Analytic Hierarchiy Process (AHP) dapat digunakan untuk membantu dalam pengisian Jabatan.

\section{b. Saran}

Dari permasalahan-permasalahan yang ada khususnya dalam hal menjalankan program sistem pendukung keputusan pengisian jabatan pada PT Prudential Life Assurance Bandar Lampung, maka penulis mengajukan beberapa saran yaitu :

1. Pengembangan lebih lanjut menjadi sistem pengisian jabatan berbasis web sehingga pengambil keputusan bisa online dimanapun mereka berada.

2. Diharapkan peneliti berikutnya menggunakan metode lain selain Analytic Hierarchiy Process

$(A H P)$

\section{DAFTAR PUSTAKA}

1. Dessler.(2011).Manajemen Sumber Daya Manusia, definisi dan fungsi bag. 1

2. Kusrini, M.Kom. (2007). Konsep dan Aplikasi Sistem Pendukung Keputusan, ANDI, Yogyakarta.

3. Rahmadi, Andriyendi. 2011. Aplikasi AHP sebagai Model SPK pemilihan Dosen.

4. Alter (2010). Sistem Pendukung Keputusan / Decision Support System (DSS).

5. Kusrini, M.Kom. (2011).Analytical Hierarkhi Process (AHP).Jurnal Pengertian Dasar AHP, Yogyakarta.

6. Suryadi, Rahmadhani (2002 : 16), Prinsip dasar AHP, (httpll.prinsip dasar Analytical Hierarkhi Process (AHP)).

7. Saaty. (1998).Penerbit “ Kriteria Dalam Penilaian Jabatan “. Penilaian kriteria dan alternatif, Jakarta.

8. Puti Purfini, (2007).Dengan Judul "Sistem Pengisian Jabatan Pada Karyawan PT UNISCOM“.

9. Widodo, Prabowo Pujdjo., Herlawati. (2011). Menggunakan UML, INFORMATIKA, Bandung.

10. Munawar, (2005), Pemodelan Visual Basic UML, Graha Ilmu, Yogyakarta.
11. Raharjo, Budi. (2011). Belajar Otodidak Membuat Database Menggunakan Mysql. INFORMATIKA, Bandung.

12. Supriyono, Wardhana, Wisnu Arya, Sudaryo. 2007. Sistem Pemilihan Pejabat Struktural Dengan Metode AHP. 